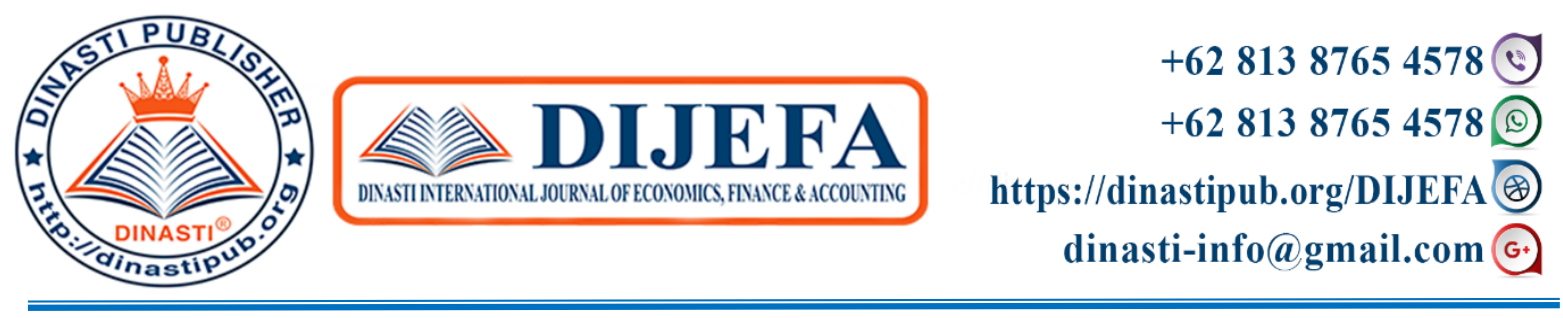

\title{
DETERMINANT FACTOR OF INTERNAL DIVIDEND PAYOUT RATIOS ON STATE OWNED ENTERPRISE
}

\author{
Eko Priyantara ${ }^{1)}$, Hakiman Thamrin ${ }^{2)}$ \\ ${ }^{1,2)}$ Mercu Buana University, Jakarta, Indonesia
}

\begin{tabular}{|c|c|}
\hline 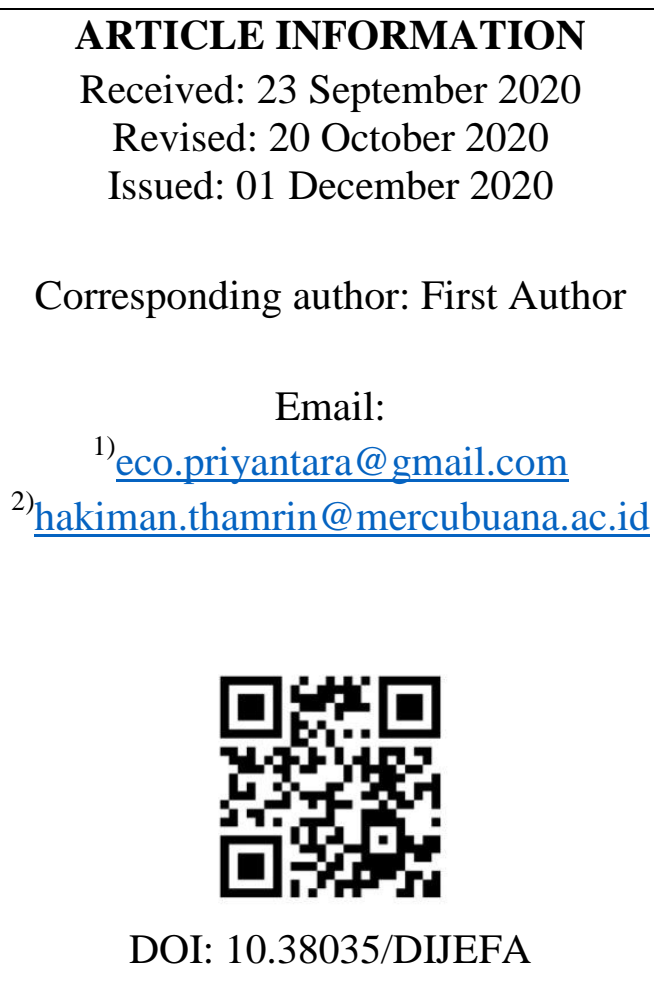 & $\begin{array}{l}\text { Abstract: These research aim to examine those impact } \\
\text { from Growth, Firm Size, Return on Assets and Debt to } \\
\text { Equity Ratio towards dividend policy of State-Owned } \\
\text { Enterprises during period 2016-2018 with } 46 \text { BUMN } \\
\text { as the research sample. In this research, the } \\
\text { independent variables were Growth, Firm Size, Return } \\
\text { on Assets and Debt to Equity Ratio, while the } \\
\text { dependent variable was Dividend Payout Ratio. The } \\
\text { results from these research found that Growth, Firm } \\
\text { Size, Return on Assets and Debt to Equity Ratio } \\
\text { simultaneously influence Dividend Payout Ratio of } \\
87.71 \% \text {. Return on Assets and Debt to Equity Ratio } \\
\text { had significant negative impact on Dividend Payout } \\
\text { Ratio, while Growth and Firm Size did not have an } \\
\text { impact on Dividend Payout Ratio. } \\
\text { Keywords: Growth, Firm Size, Debt to Equity Ratio, } \\
\text { Return on Assets, Dividend Payout Ratio. }\end{array}$ \\
\hline
\end{tabular}

\section{INTRODUCTION}

Non-Tax State Revenue (PNBP) plays an important role in supporting the achievement of state revenue target which set by APBN. During these 2015-2019 period, PNBP realization tended to increase, mainly influenced by the optimization and performance of each PNBP component. Within this timeframe, PNBP SDA still contributed significantly to whole PNBP realization, reaching an average of 36.7 percent. Beside that, an improving service performance at $\mathrm{K} / \mathrm{L}$ and increasing profitability of State-Owned Enterprises (BUMN) also bring positive impact towards the achievement of PNBP realization. 
During period 2015-2019 the segregated revenue from state assets still originated mainly from distribution of BUMN profits or dividends. During this period, BUMN performance continued to experience positive developments, both in terms of assets, equity, income and operated profits. This shows that in general, SOEs were able to cope with pressures from global economic conditions. As a result from its positive developments in BUMN performance, the contribution of BUMN to State Budget in 2015-2019 period, particularly from dividend payments, continues to increased. During this period, those contribution of BUMN from dividend payments to PNBP has increased by average of 14.9 percent per year. Supporting this statement, the revenue target of BUMN's profits share were also increased from IDR 31 trillion (2012) to IDR 45.1 trillion (2018).

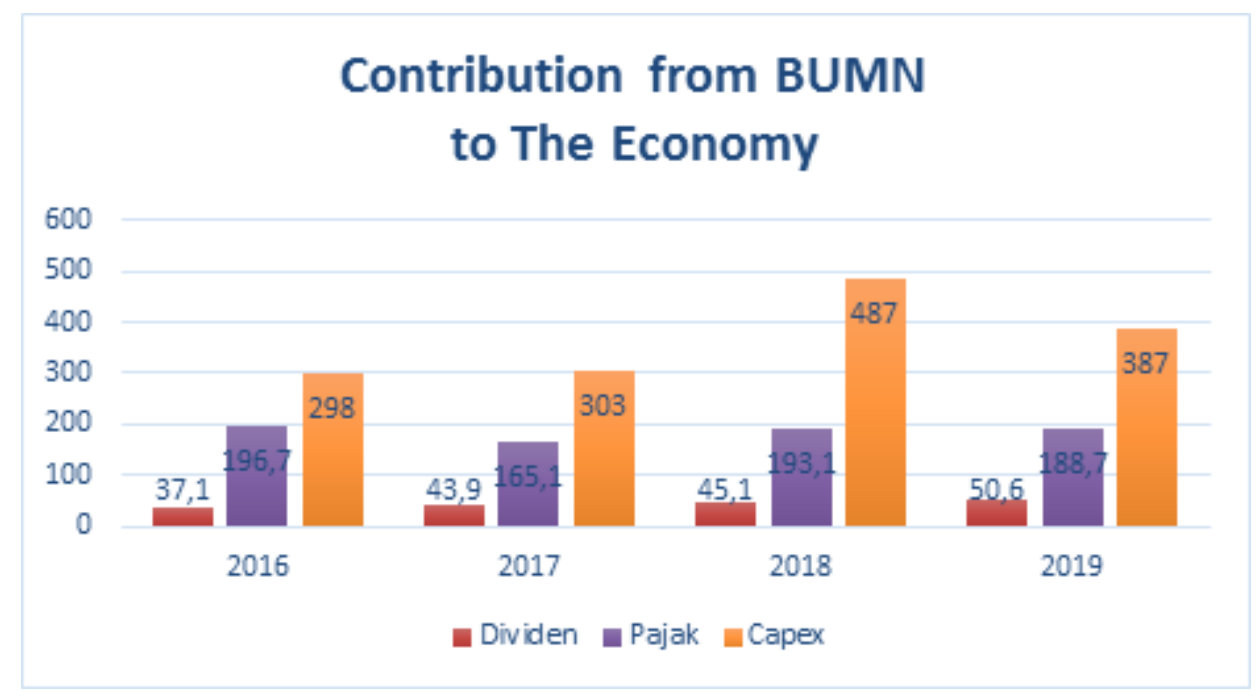

Figure 1. Contribution from BUMN to The Economy

Source: Ministry of Finance

The determination of government's target share from BUMN's profit above was carried out by recognized the optimal benefits for the country. From the BUMN side, the determination of target amount was taken into profitability of BUMN, especially for several BUMNs which included in BUMN group with the largest dividend contributors. Beside that, the determining of government's target share of BUMN profits were also carried out by taking into consideration from company's funding capacity, especially on the level of solvency. Determination of dividends were also takes into ability of SOEs to fund profitable investments in order to maintain business continuity and efforts to reduce the market value of SOEs listed on stock exchange and not violate regulations or covenants that bind on BUMN. Meanwhile, from the Government aspect had role to ensuring that planned programs and activities can be funded from targeted revenue sources, including those from segregated state assets.

This research used financial ratio variables in predicting BUMN dividend policy, which is the profitability ratio was represented by Return on Assets (ROA), the solvency ratio was 
represented by Debt to Equity Ratio (DER), firm size and growth. The growth of BUMN from 2016 to 2018 was fluctuated, the firm size of BUMN tends to increase along with the increase in BUMN assets as a whole. From these profitability aspect that proxied by ROA, it could defined that the ability to earned profit from assets has decreased from 2016-2018. Meanwhile, the solvency aspect which proxied by DER from 2016-2018 was increased. From 2016 to 2018 , the DPR continued to increase along with the increasing number of dividend payments to the state, in the other hand this was not balanced to aggregate profit of BUMN which tended to be flat.

Table 1. Growth, Firm Size, ROA, DER, and DPR in BUMN during 2016 - 2018

\begin{tabular}{|lccc|}
\hline \multicolumn{1}{|c}{ Description } & $\mathbf{2 0 1 6}$ & $\mathbf{2 0 1 7}$ & $\mathbf{2 0 1 8}$ \\
\hline Grow th (\%) & $-2,67 \%$ & $18,20 \%$ & $14,49 \%$ \\
\hline Firm size & 15,16 & 15,29 & 15,4 \\
\hline ROA (\%) & $2,70 \%$ & $2,60 \%$ & $2,30 \%$ \\
\hline DER (kali) & 2,01 & 2,24 & 2,27 \\
\hline DPR (\%) & $31,65 \%$ & $32,60 \%$ & $35,81 \%$ \\
\hline
\end{tabular}

Source: ILKPN, Ministry of Finance and Ministry of BUMN (processed)

Research which conducted by Sinabutar and Nugroho (2015) were explained that Sales Growth had negative impact on Dividend Payout Ratio (DPR). This research was different from research by Bushra and Mirza (2015) which stated that Sales Growth had positive influence on DPR. Meanwhile, research which carried out by Sari (2018) shows that Sales Growth has influence on DPR.

Research which carried out by Rehman and Takumi (2012) shows that DER had positive impact on DPR. Meanwhile, research by Nidar and Gunawan (2016) stated that DER had negative impact on the DPR. Furthermore, different research results were also shown from the results from research by Sari (2018) which found that DER had no impact on DPR.

Research which conducted by Sari (2018) found that Firm Size had positive influence towards DPR. Meanwhile, research that carried out by Nidar and Gunawan (2016) which defined that Firm Size had negative influence on DPR. Khan and Ahmad's research (2017)has shown that Firm Size has no impact towards DPR.

Research conducted by Rehman and Takumi (2012) shows that ROA had positive impact on DPR. Meanwhile, Nurwulansari and Rikumahu (2018) stated that ROA had negative impact on DPR. Furthermore, research that conducted by Sinabutar and Nugroho (2015)were concluded that ROA had no impact towards DPR. 
By looking at these problems and those inconsistency from these prior research, its necessary to do further investigate with the title of "Determinant Factor of Internal Dividend Payout Ratio on State Owned Enterprise during period 2016 - 2018".

\section{LITERATURE REVIEW}

\section{Irrelevant Dividends}

According to Modigliani and Miller (1961), dividend payout ratio had no impact over company's stock price or cost of capital. Modigliani and Miller were stated that dividend payout ratio was irrelevant then the company value was determined by the earning power of company's assets.

\section{Bird in the Hand Theory}

The Bird in The Hand Theory which developed by Gordon and Litner (1956) revealed that the level of profit will considered increased if the dividend distribution is reduced, because investors are more confident about receiving dividends than increasing the capital value (capital gain) that will result from retained an earnings.

\section{Tax Preference Theory}

If capital gains are deducted with tax at a lower rate than the tax on dividends, then stocks which have high growth are more attractive. In the other hand, if capital gains were taxed the same as income on dividends, then capital gains will be reduced. Therefore, this theory suggests that companies should determine low dividend payout ratio or even not pay dividends (Litzenberger and Ramaswamy, 1979).

\section{Pecking Order Hypothesis}

The Pecking Order Hypothesis was first introduced by Meyrs and Majluf (1984), they revealed that companies prioritize internal funds rather than external funds in funding activities. The Pecking Order Hypothesis according to Myers (1984). According to these four assumptions, such as: dividend policy is constant (sticky), internal funds way better than external, when using external funds choose the risk-free securities, if required lots of external funds then choose securities, risk free debt, risky debt, convertible security, preferred stock, common stock.

\section{Agency Theory}

According to Jensen \& meckling (1976) agency cost is the sum of charges to make oversight of agents. The agency theory suggests that the dividends help reduce the agency's cost in connection with the separation of ownership and control of the company. (Jensen \& Meckling, 1976; Easterbrook, 1984).

\section{Growth}


Sales growth describes as changes both term increase or decrease in sales from year to year which could be seen from each company's income statement.

$$
\text { Growth }=\frac{S t-S t-1}{S t-1} \times 100 \%
$$

\section{Firm Size}

Firm size could be measured through natural logarithm of total assets, because of large size company usually has high resources.

Firm Size $=$ Logarithm Natural of Total Assets

\section{Debt to Equity Ratio}

Debt to equity ratio was measured by dividing total liabilities with equity.

$$
D E R=\frac{\text { Total Debt }}{\text { Equity }}
$$

\section{Return on Assets}

Return on Assets could be measured by dividing earning after tax with total assets.

$$
R O A=\frac{\text { Earning after tax }}{\text { Total Assets }}
$$

\section{Dividend Payout Ratio}

Dividend Payout Ratio was measured by comparing total dividends with company's net income.

$$
D P R=\frac{\text { Total Dividend }}{\text { Net Income }}
$$

\section{Theoretical Framework}

Theoretical framework from this research could be described as in these picture below.

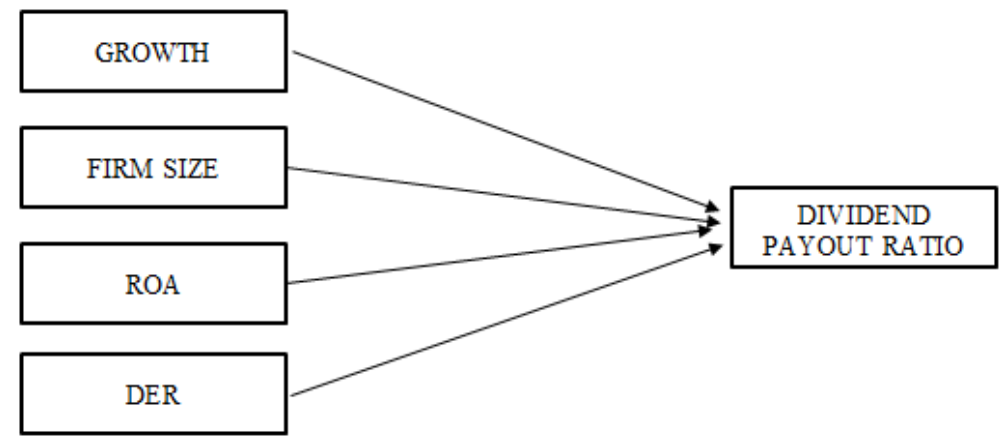

Figure 2. Theoretical Framework 


\section{Hypothesis}

The research hypothesis could be describe as follows:

Hypothesis 1: Growth had negative impact towards dividend payout ratio

Hypothesis 2: Firm size had positive impact on dividend payout ratio.

Hypothesis 3: Return on assets had positive impact on dividend payout ratio.

Hypothesis 4: Debt to equity ratio had negative influence on dividend payout ratio.

\section{RESEARCH METHODS}

This research method used the correlational research method, whereas could be used to discover those connection between two or more variables with other variables and how a variable would affects each other. Type of data that used in this research was quantitative data. Those independent variables were Growth, Firm Size, Debt to Equity Ratio, and Return on Assets, while dependent variable was the Dividend Payout Ratio. Total population in this research was 113 BUMN under the guidance and supervision of Minister of BUMN and 4 BUMN under the guidance and supervision by Ministry of Finance for the 2018 period. Sampling was carried out by purposive sampling method with purpose to gained a representative sample with these following criteria: 1) financial reports during the observation period; 2) BUMN has experiences profits during these observation period; and 3) the BUMN shall distribute dividends during these observation period. Based on these criteria, The number of samples which fill its criteria on this research were 46 companies. Data collection technique for the purposes of this research was carried out by documentation with collecting all secondary data which earned from the Summary of State Company Financial Statements (ILKPN) reported by the Directorate General of State Assets, Ministry of Finance 2016-2018. Data analysis method used multiple regression test. The data analysis technique used panel data regression analysis.

\section{RESULTS AND DISCUSSION}

\section{Panel Data Regression Equations}

Table 2. Estimation Results from Fixed Effect Model

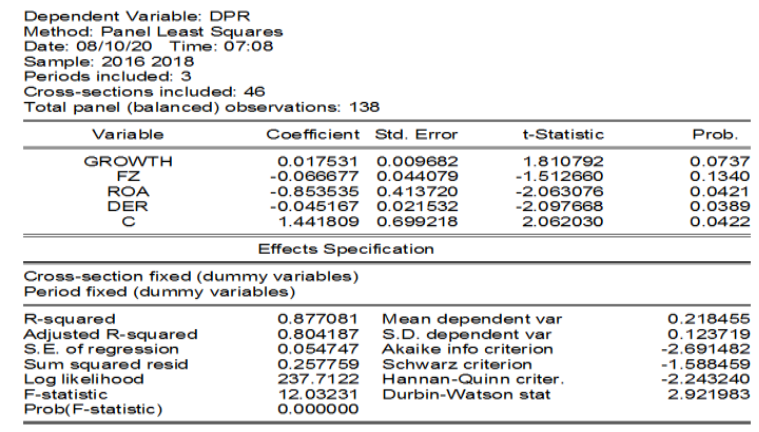




\section{Source: Eviews Application Output 9}

From table estimation results above, then the model could be created as panel data analysis towards those factors which affects to dividend payout ratio from 46 BUMN companies during period 2016-2018. These regression equation from these panel data above could be written as follows:

$\mathrm{Y}=1.441+0.017 \mathrm{X} 1-0.067 \mathrm{X} 2-0.854 \mathrm{X} 3-0.045 \mathrm{X} 4+\varepsilon$

The regression equation above shows the constant $\mathrm{C}$ value of 1.441 , meaning that if value from all independent variables was constant (0), then the value of dependent variable from dividend payout ratio was 1.441 .

\section{Statistical Test}

The statistical test in this research were includes determination (R2), joint significance test ( $\mathrm{F}$ statistical test) and individual parameter significance test ( $\mathrm{t}$ statistical test). Based on Table 5 above, it could be concluded that:

1) The R-Square value was 0.877081 . This shows that statistically $87.71 \%$ of dividend payout ratio from $46 \mathrm{BUMN}$ companies could explained by independent variables in the model (Growth, Firm size, ROA and DER) and the remaining of $12.29 \%$ was influenced by other independent variables outside these research model.

2) The F-statistic probability value was 0.000000 (significant at $5 \%$ ), meaning that the independent variables (Growth, Firm size, ROA and DER) togetherness affect the dependent variable (dividend payout ratio) in 46 BUMN companies during 2016 -2018.

3) ROA and DER had significant negative impact towards Dividend Payout Ratio at 46 BUMN companies. This proven by the $\mathrm{t}$-count value $>\mathrm{t}$ - table and the probability value $<$ 0.05 .

4) Growth and Firm Size had none influence towards Dividend Payout Ratio at 46 BUMN companies. This proven by the value of $<\mathrm{t}$ table and the probability value $>0.05$.

\section{Discussion}

The results from this research was indicated that growth had no impact on dividend payout ratio from 46 BUMN companies. Meaning that dividend policy was not determined by the company's growth. Whether it is BUMN which carrying out assignments or business expansion or BUMN which already in a mature stage, dividend policy is the same. The company's growth could utilized the advantage of funds in the form of internal and external funds. Internal funds include reserved profits, while external funds could be form as issuance of shares or debt. These empirical result did not supported the theory from Pecking Order Hypothesis by Meyrs \& Majluf (1984) which quoted that companies would prioritized those internal funds than external funds when it comes in funding activities. These results shows that company funds had impact on dividend policy. This were line with research by Sari (2018) which found that sales growth had no impact on DPR. 
The results from this research was indicated that firm size variable had no impact on dividend payout ratio. This finding was contrasts with most of prior research which explained that firm size had impact on dividend policy, where large companies have the convenience in gaining profits and sources of funding so they would be able to pay higher dividends. However, state-owned companies are mostly owned by the State so the dividend policy is different from private companies. The results of this study do not support the argument of agency costs. According to the theory of agency, dividend Payment will give rise to the need for external financing (external financing), which will further increase the company's monitoring activities by creditors (Easterbrook, 1984). However, these empirical results were in line with research by Khan and Ahmad (2017) who found that Firm Size had no impact towards DPR.

The results of this research was indicated that ROA had negative and significant impact on dividend payout ratio from this $46 \mathrm{BUMN}$ companies. ROA is measured from net profit after tax to total assets, it used as a reflection of the company's ability to use investment as operations in order to generate profitability. The greater ROA, the better company's performance because the rate of return was greater. However, in recent years there contrasts was occured, amid global uncertainty and increasingly competitive global competition, for sample of companies used there are several companies that have high profits but these companies invest so many of their funds in fixed assets, this may results in reduced dividend payments made by these company. These research results were in line with agency theory. According to the theory of agency, dividend Payment will give rise to the need for external financing (external financing), which will further increase the company's monitoring activities by creditors (Easterbrook, 1984). These results were in line with research by Nurwulansari and Rikumahu (2018) and John dan Muthusany (2010) which found that ROA had negative impact on DPR.

The results from this research was indicate that DER had negative and significant impact towards dividend payout ratio from these 46 BUMN companies. Meaning that the higher DER level, the lower dividend payout ratio. So the greater the percentage of debt, the smaller the percentage of companies paying dividends. These research outcomes were in line with the Pecking Order Hypothesis theory. The higher debt to equity ratio from a company, the more likely company will pay dividends in small amount to their shareholders in order to compensate on retained earnings allocations to pay its liabilities and increase in funding needs for capital expenditures for business expansion so it could financed itself first with these internal funds. These results were in line with research by Nidar and Gunawan (2016), Zulkifli, et al (2017) who found that DER had negative impact towards DPR.

\section{CONCLUSION AND SUGGESTION}

\section{Conclusion}

According to these research results and discussion that has been stated previously, there are several conclusions from this research that could be explained as follows: 1) Growth which measured by sales growth had no impact on Dividend Payout Ratio; 2) Firm Size had no 
influence on Dividend Payout Ratio; 3) Return on Asset had negative impact over Dividend Payout Ratio; 4) Debt to Equity Ratio had negative influence on Dividend Payout Ratio

\section{Suggestion}

Based on these conclusions which authors described above, these following suggestions from the authors could be seen such as:

1) Investors and Government as well as policy makers to determined the dividend policies for BUMN should considered about Growth, Firm Size and Return on Assets as factors in determining the rate of return on investment in form of Dividend Payout Ratio (DPR). This is so important because these research results shows that Growth, Firm Size and Return on Assets had significant impact towards Dividend Payout Ratio.

2) These observation year should be extended to find out those consistency of the influence from these variables above (Growth, Firm Size and Return on Assets, and Debt to Equity Ratio) towards Dividend Payout Ratio.

3) Adding another independent variables outside these independent variables which studied (Growth, Firm Size and Return on Assets, and Debt to Equity Ratio).

\section{REFERENCES}

Akbar, A., \& Thamrin, H. (2020). Analysis of Effect of CAPR, DAR, ROA and Size on Tax Avoidance. Dinasti International Journal of Management and Science, 1(5):706-718.

Ang, R. (1997). Buku Pintar Pasar Modal Indonesia. Jakarta: Media Staff Indonesia.

Bushra, A., \& Mirza, N. (2015). The Determinants of Corporate Dividend Policy in Pakistan. The Lahore Journal of Economics, 20(2), 77-98.

Easterbrook, F. (1984). Two Agency Costs Explanations of Dividend, American Economic Review\| 74, 650-659.

Farinha, J. (2003). Dividend Policy, Coporate Governance and The Managerial Entrenchment Hypothesis: An Empirical Analysis. Journal of Business Finance Accounting, 30(9-10), 1173-1209.

Gordon, Myron and John Lintner. (1956). Distrribution of Income of Corporations Among Dividend, Retained Earning and Taxes. The American Economic Review. 46(2): 97-113.

Hanafi, M. Mamduh. (2004). Manajemen Keuangan. Yogyakarta: BPFE.

Khan, F.A., \& Ahmad, N. (2017). Determinant of Dividend Payout: An Empirical Study of Pharmaceutical Companies of Pakistan Stock Exchange (PSX). Journal of Financial Studies \& Research, Vol. 2017, DOI: 10.5171/2017.538214.

Litzenberger, R. H. And Ramaswamy, K. (1979). The Effect of Personal Taxes and Dividend on capital Asset Prices: Theory and Empirical Evidence. Journal of Financial Economics, 7, 163-195.

Miller, M. H., \& F. Modigliani. (1961). Dividend Policy, Growth, and the Valuation of Shares. Journal of Business. Vol. 34 (4): 411-433.

Myers, S. C., dan N. S. Majluf. (1984). Corporate Financing and Investment Decision When Firm Have Information That Investor do not Have. Journal of Financial Economic, Vol. 13 (2): 187-221.

Nidar, S.R., \& Gunawan, AA. (2016). Dividend Policy In Indonesia State Owned Enterprises. International Journal Of Scientific \& Technology Research, 5(06), 238-242. 
Nurwulansari \& Rikumahu, B. (2018). Determinant of Dividen Payout Ratio: A Study of Listed Companies in Indonesia Stock Exchange. International Seminar \& Conference on Learning Organization. ISCLO 6th, 2018.

Prihantoro (2003). Estimasi Pengaruh Dividen Payout Ratio pada Perusahaan Publik di Indonesia. Jurnal Ekonomi dan Bisnis, No.1, Jilid 8, pp: 7-14.

Rehman \& Takumi (2012). Determinants of Dividend Payout Ratio:Evidence From Karachi Stock Exchange. Journal of Contemporary Issues in Business Research, $1(1), 20-27$.

Riyanto, B. (2001). Dasar-Dasar Pembelanjaan Perusahaan. Yogyakarta: BPFE.

Sari, W.R. (2018). Dividend Policy of Indonesian State-Owned Enterprises. Telaah Bisnis, $18(1)$.

Saxena, A,K. (1999). Determinant of Dividen d Policy:Regulated Versus Unregulated Firms. The Journal of Finance.

Sinabutar \& Nugroho. (2015). Dividend Payout Ratio In Indonesian Consumer Goods Industry: Panel Analysis and Determinant daftar Factors In 2004-2013. Journal of Business and Management, 4(4), 453-464.

Zulkifli, Endri, \& Kurniasih, A. (2017). Determinan Internal Dividend Payout Ratio Perusahaan Farmasi Terdaftar di Bursa Efek Indonesia. Jurnal Keuangan dan Perbankan, 21(2): 238-252. 